\title{
The Feeding Habits of Rose Bitterling in the Shin Tone River
}

\author{
Gultneh Solomon, ${ }^{*}$ Makoto ShImIzU, * and Yukio NosE* \\ (Accepted October 6, 1984)
}

\begin{abstract}
The gut contents of rose bitterling consist mainly of diatoms, with a smaller proportion of crustaceans and green algae. Although flagellates are found in the gut together with diatoms, crustaceans, and green algae, they are not considered to be an important food item. Seasonal variation in the gut composition takes place so that in October and November diatoms make 83$88 \%$ of the composition while green algae and crustaceans are found in small percentages. No difference was found in the food compositions of larval and older fish guts examined. A high percentage of empty guts were observed in fish after hours of darkness, and it is assumed that the fish is a day-active feeder that looks for food using visual cues.

The compositions of the gut contents and that of the river plankton are more or less similar and it is not clear whether or not the fish show preference for any particular type of food organism.
\end{abstract}

Little work has been done on the food and feeding habits of rose bitterling (Rhodeus ocellatus ocellatus) although some remarks are available from scattered studies on general information about this species. As a continuation of the research on rose bitterling population in the Shin Tone River, the food composition, the seasonal feeding habits and the planktonic organisms in the river were studied.

\section{Materials and Methods}

A total of 728 fish collected from February to November in 1980 were examined for their gut contents. Whole gut was dissected out of the fish and opened by gently teasing it under a low power binocular microscope. The contents were picked out on a microscopic slide, flooded with distilled water and examined. Each organism was identified up to the genus level and its presence or absence recorded. The monthly occurrence of each item is expressed as a percentage of the total frequency occurrence of items in all the guts examined in the monthly sample.

Larval fish measuring from $8-10 \mathrm{~mm}$ in length were collected on June 30th, 1981 and their gut contents were also examined in a similar way to determine if their feeding habits differed from the adult fish. During September 24th-25th fish samples were collected at hourly intrevals over a 24-h period to determine if a diurnal change in its feeding activities takes place. In all cases the specimens were preserved in $10 \%$ formalin immediately after collection.

Monthly plankton samples were collected from the river using the plankton net number XX13 with mesh size of $95 \mu$. Each time two collections were made and samples were preserved in 5\% formalin. Before counting, the sample was agitated thoroughly by continuous shaking. The sample was transferred by a pipette into a micrometer glass slide of $1.109 \mathrm{~m} l$ capacity, covered by a cover glass and placed on the microscope counting stage. Cells and colonies were counted under $\times 10$ or $\times 20$ objectives, while very small forms were counted with a magnification of $\times 40$. The total number of cells or colonies was found by multiplying the number of individuals or colonies, counted in the transects with the ratio of the whole area of the inspected transects. Counting was done more than once and the average of counts was used.

\section{Results}

\section{Food Composition in the Fish Gut}

The percentage composition of organisms in the gut of fish sampled is presented in Table 1 and Fig. 1(a). The gut contents of rose bitterling most of the time consisted of more than $50 \%$ of diatoms, and the rest of the gut content consisted of crustaceans, green algae and flagellates. Among the diatoms, Navicula sp. and Melosira sp. were the most common. Daphnia sp. and Bosmina

* Department of Fisheries, Faculty of Agriculture, University of Tokyo, Bunkyo, Tokyo 113, Japan (G. ソロモン・清水 誠・能勢幸雄: 東京大学莀学部水産学科). 
Table 1. Percentage occurrence of food items in the gut calculated using the total number of occurrence of each item in the gut examined

\begin{tabular}{|c|c|c|c|c|c|c|c|c|c|}
\hline \multirow{2}{*}{ Items in gut } & \multicolumn{9}{|c|}{ Month } \\
\hline & Feb. & Mar. & Apr. & May & June & July & Sept. & Oct. & Nov. \\
\hline Diatoms & 56.3 & 36.1 & 18.5 & 40.0 & 51.3 & 62.5 & 23.9 & 82.5 & 88.0 \\
\hline Melosira & 14.7 & 11.1 & 7.1 & 20.0 & 15.9 & 54.2 & 23.9 & 47.8 & 38.0 \\
\hline Synedra & - & - & - & - & 9.8 & - & - & - & 7.2 \\
\hline Navicula & 41.6 & 25.0 & 11.4 & 20.0 & 15.9 & 8.3 & 一 & 34.7 & 42.8 \\
\hline Bacilaria & - & - & - & - & 1.2 & - & - & - & - \\
\hline Pinnularia & - & - & 一 & - & 4.8 & - & - & - & - \\
\hline Climacosphenia & - & - & - & - & 3.7 & - & - & - & - \\
\hline Crustaceans & 1.1 & - & 55.7 & 20.0 & 23.2 & 4.2 & 28.6 & 8.7 & - \\
\hline Daphnia & - & - & - & 8.0 & 19.5 & 4.2 & - & - & - \\
\hline Bosmina & 1.1 & - & 55.7 & - & - & - & 28.6 & 8.7 & - \\
\hline Cyclops & - & - & - & 12.0 & 3.7 & - & 一 & - & - \\
\hline Green algae & 25.0 & 22.2 & 15.8 & 16.0 & 12.2 & 20.8 & 2.5 & 8.8 & 4.8 \\
\hline Pediastrum & - & - & - & - & - & 8.3 & - & - & - \\
\hline Scenedesmus & - & - & 7.0 & - & - & - & 2.5 & - & - \\
\hline Stigeoclonium & 7.6 & 2.8 & 1.4 & - & 2.4 & 8.3 & - & 4.4 & - \\
\hline Oedogonium & 15.2 & 19.4 & 7.4 & - & - & - & - & - & - \\
\hline Pleurotaenium & - & - & - & - & 3.7 & 4.2 & - & - & - \\
\hline Closterium & 2.2 & - & - & 16.0 & 6.1 & - & - & 4.4 & 4.8 \\
\hline Phytoflagellates & 17.1 & 41.7 & 10.0 & - & 1.2 & 4.2 & 42.5 & - & 4.8 \\
\hline Eudorina & - & - & - & - & - & 4.2 & - & - & - \\
\hline Arcella & - & - & - & - & - & - & 33.0 & - & - \\
\hline Euglena & 17.1 & 41.7 & 10.0 & - & 1.2 & - & 9.5 & 一 & 4.8 \\
\hline Blue green algae & 0.5 & - & - & - & 9.7 & - & - & - & 2.4 \\
\hline Microcystis & 0.5 & - & - & - & 2.4 & - & - & - & 2.4 \\
\hline Oscillatoria & - & - & 一 & - & 7.3 & - & - & - & - \\
\hline Rotatoria & - & - & - & 24.0 & 2.4 & 8.3 & 2.5 & - & - \\
\hline Brachionus & - & - & 一 & 24.0 & 2.4 & 8.3 & 2.5 & 一 & - \\
\hline Total no. of items & 197 & 36 & 70 & 25 & 82 & 24 & 42 & 23 & 42 \\
\hline No. of guts exam. & 95 & 40 & 55 & 30 & 50 & 20 & 33 & 18 & 29 \\
\hline No. of empty guts & 13 & 15 & 4 & 3 & 6 & 6 & 11 & 6 & 9 \\
\hline
\end{tabular}

sp. constituted the bulk of the crustaceans found, with Cyclops sp. occurring in minor percentages. The most frequently found green algae were Stigeoclonium sp., while Euglena sp. was the most common flagellate. In addition to these four groups, blue green algae (Microcystis sp. and Oscillatoria sp.) and rotatoria (Brachionus sp.) were found in low percentages.

During most of the year the food composition was made up mainly of diatoms but varied considerably due to the variation in percentage of other items in the gut, mainly that of crustaceans and flagellates (Fig. 1 and Table 1). This variation in diatoms was $18-62 \%$ from February to September while in October and November it was $82-88 \%$. Crustaceans also showed large variation in their monthly percentage composition. For example the composition of crustaceans was $56 \%$ in April and $4 \%$ in July, while very few or no crustaceans appeared in the composition in winter. The percentage composition of green algae was high (12-25\%) from February to July and low (2-9\%) from August to November.

\section{Feeding Habit of Larval Fish}

Twenty larval fish collected on June 30th, 1981 had their gut contents examined and the percentage occurrence of organisms in the gut examined is shown in Table 2. Diatoms and green algae were the most common organisms observed, Navicula sp. and Melosira sp. being the most common diatoms. Crustaceans were represented by Daphnia sp. and Brachionus species. Euglena sp. was found in all the guts examined, however, these organisms remained whole and retained their pigments throughout the gut to the anus in both larval and adult fish guts and thus are not considered to constitute a food item of neither the 

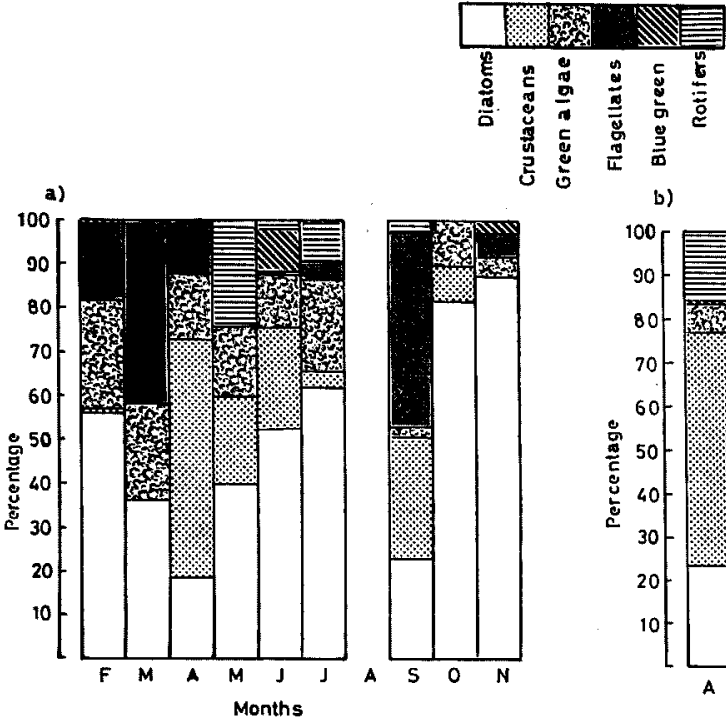

b)

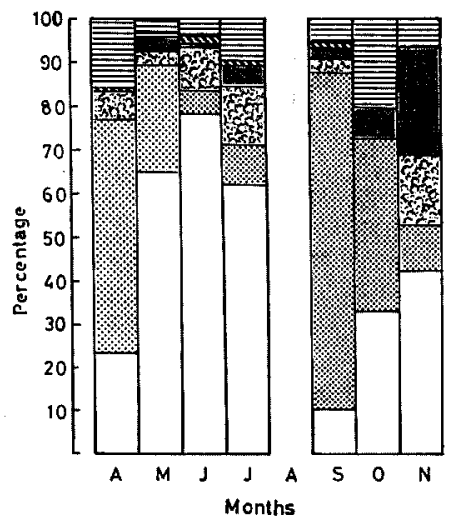

Fig. 1. Monthly percentage composition of organisms in the gut of rose bitterling (left hand side (a)) and monthly percentage composition of plankton in the Shin Tone River (right hand (b)). Symbols show types of organisms in both the gut content and in the river.

Table 2. Frequency occurrence of organisms in the gut of larval fish

\begin{tabular}{lc}
\hline Organisms & Occurrence (\%) \\
\hline Diatoms & 75 \\
Melosira & 40 \\
Synedra & 100 \\
Navicula & 25 \\
Cyclotella & \\
Crustaceans & 50 \\
Daphnia & \\
Green algae & 20 \\
Scenedesmus & 20 \\
Closterium & 20 \\
Cosmarium & \\
Phytoflagellates & 100 \\
$\quad$ Euglena & \\
Rotifers & 20 \\
Brachionus & 20 \\
\hline No. of fish examined & 0 \\
No. of empty guts & \\
\hline
\end{tabular}

larval nor the adult fish.

\section{Diurnal Change in Feeding Activity}

Fig. 2 shows the diurnal change in the percentage of empty gut observed during a 24-h cycle from September 24th to 25th, 1981. After 9:00 pm most of the fish had empty guts and it is clear that the fish stop feeding after sunset
(17: 36) and immediately start feeding at the start of sunrise $(5: 30)$. From this it is assumed that the fish is a day-active feeder that uses visual cues for food detection. From analysis of the data on the fish catch during the same period it was found that the catches were higher during the daytime, and the nighttime catches were very low or nil until dawn when the fish catch started to increase.

\section{Plankton Composition in The Shin Tone River}

Monthly calculated densities of plankton in the river expressed as number of organisms per liter are shown in Table 3. Diatoms, crustaceans, green algae and flagellates show high densities and large number of species in the environment. The most frequently observed rotifer was Brachionus sp., and that of blue green algae was Microcystis species. The most dominant diatoms were Melosira sp. and Synedra species. Cyclops sp., and Nauplius followed by Daphnia sp. were the most dominant crustaceans. The most frequently observed green algae were Spaerocystis sp. and Stigeoclonium species, while Vorticella sp., Eudorina sp. and Ceratium sp. were the most common flagellates.

The seasonal percentage composition of the major groups of plankton in the river are shown in Fig. 1(b). Diatoms make the highest percentage composition during most of the year, 


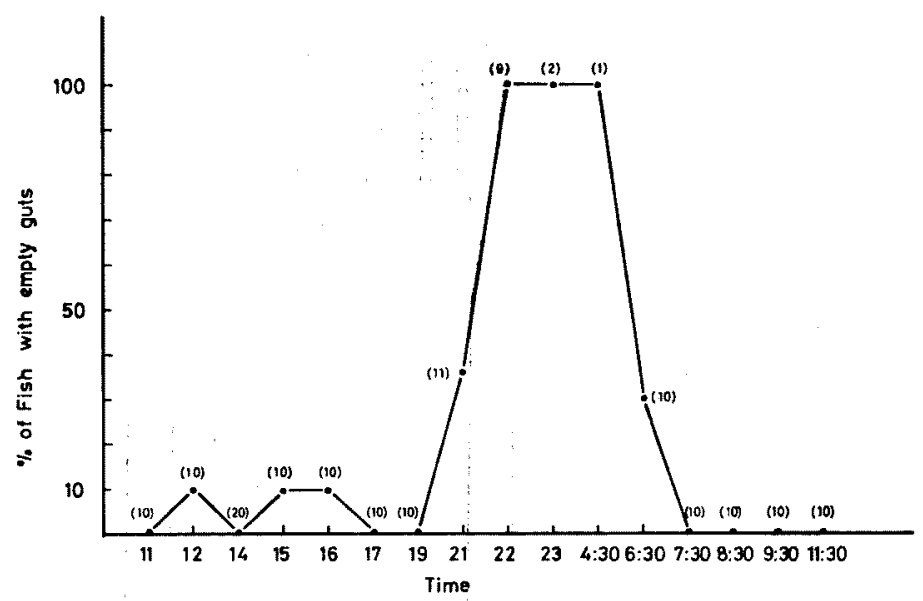

Fig. 2. Diurnal change in the percentage of empty fish guts observed from 24-25 Sept. 1981. Figures in brackets show the sample size. (sunset $=17: 36$, sunrise $=5: 30$ ).

followed by crustaceans and green algae. The number of species in each of the plankton groups decreases in October and November (Table 3) and their densities (except for flagellates) also drops drastically from September onwards.

The compositions of the gut contents and that of the environment show some similarities in general (Figs. 1a \& b), and it is not clear whether or not the fish show preference for any particular type of food organism.

\section{Discussion}

Although the gut content of rose bitterling consisted mostly of diatoms, crustaceans, and green algae, most of the gut samples examined also contained unidentifiable matters that are assumed to be organic materials which are detritus in nature. It is probable that this might be used by the fish as a food source and thus the fish may be classified as an omnivore. Very little information is available on the feeding habits of other similar fish groups. For a comparison the following brief remarks of OKADA ${ }^{12}$ on some of the species might be useful. Biwatanago or Itasempara (Acheilognathus longipinnis Regan)-omnivorous; Kanehira ( $A$. rhombeus Temminck et Schlegel)omnivorous; Aburabote (A. lanceolates Temminck et Schlegel)-feeds on crustaceans, worms and aquatic insects; Zenitanago (Pseudoperilampus types Bleeker)-omnivorous feeding mainly on microorganisms and organic matters. From this information, it can be seen that most of these minnows feed on a mixed diet of phytoplankton, zooplankton and detritus materials.

The contents of several fish guts were examined by segments and it was found that all the phytoflagellates, for example, Euglena sp., and Eudorina sp., had remained whole and that pigmentation was retained all through the gut to the anus. SPATARU ${ }^{2)}$ working on the silver carp, Hypophthalmichthys molitrix (Val), and other workers have also reported similar observations on phytoflagellates in the guts of the silver carp and other fish species. From these observations and informations it is concluded that these phytoflagellate species do not constitute the food components of the fish.

It can be said that there is no drastic change in the composition of the diet as the fish grow. Large sized crustaceans are found to be more common both in number of species and density in non-larval fish. This may be an expression of increase in the maximum size of the organisms eaten as the fish grow. AlleN ${ }^{37}$ has shown that perch would require to eat very large amounts of small crustaceans if they did not change their diet as they grew. Unlike perch which grow to a large size, rose bitterling never grow so large as to need to change their diet from those organisms that can be eaten by the smallest fish.

The seasonal feeding activity of the fish was determined by recording the presence and absence of empty guts in the monthly fish samples. The results found by this method did not reveal any particular trend. For example, the percentage of empty guts in the monthly samples did not show any clear difference between summer and winter 
Table 3. Calculated number of planktonic organisms in the Shin Tone River expressed as n/liter

\begin{tabular}{|c|c|c|c|c|c|c|c|}
\hline \multirow{2}{*}{ Species } & \multicolumn{7}{|c|}{ Month } \\
\hline & Apr. & May & June & July & Sept. & Oct. & Nov. \\
\hline \multicolumn{8}{|l|}{ Diatoms } \\
\hline Melosira & 115 & 896 & 2,715 & 1,965 & 275 & 135 & 70 \\
\hline Synedra & 120 & 450 & 135 & 145 & 20 & & 10 \\
\hline Navicula & 60 & 40 & 20 & 15 & 10 & 65 & 65 \\
\hline Gyrosigma & & 50 & 30 & 75 & & & \\
\hline Bacillaria & & & & & 15 & & \\
\hline \multicolumn{8}{|l|}{ Crustaceans } \\
\hline Daphnia & 30 & 35 & 25 & 10 & 350 & & \\
\hline Diaptomus & & & & & 10 & & \\
\hline Diaphnosoma & & & & 20 & 35 & 55 & \\
\hline Bosmina & & & 20 & & & & \\
\hline Cyclops & 400 & 120 & 40 & 95 & 330 & 60 & 40 \\
\hline Nauplius & 255 & 340 & 160 & 195 & 1,820 & 125 & \\
\hline \multicolumn{8}{|l|}{ Green algae } \\
\hline Pediastrum & & 10 & 100 & 65 & 10 & & \\
\hline Scenedesmus & & & & 10 & & & \\
\hline Stigeoclonium & 10 & 40 & 15 & & 30 & & \\
\hline Oedogonium & 10 & & 130 & & & & \\
\hline Closterium & 20 & & 35 & 250 & & & \\
\hline Strourastrum & & & 70 & 20 & & & \\
\hline Sphaerocystis & 40 & 40 & 20 & 165 & 45 & & 55 \\
\hline \multicolumn{8}{|l|}{ Phytoflagellates } \\
\hline Eudorina & & & 20 & & 20 & & 20 \\
\hline Vorticella & 10 & 40 & 15 & 140 & 30 & 45 & \\
\hline Dinobryon & & & & & 30 & & \\
\hline Ceratium & & 40 & & & 15 & & 65 \\
\hline \multicolumn{8}{|l|}{ Blue green algae } \\
\hline Microcystis & 10 & 10 & 50 & 20 & 20 & & \\
\hline \multicolumn{8}{|l|}{ Rotifers } \\
\hline Asplanchna & 10 & & & & 10 & 95 & \\
\hline Brachionus & 120 & 70 & 50 & 290 & 115 & 25 & 20 \\
\hline Filinia & 25 & & & 10 & 10 & & \\
\hline Polyarthra & 40 & & & & & & \\
\hline
\end{tabular}

season where difference in feeding activity is anticipated. It is only in March 1981 that a significantly higher percentage of empty guts $(25.4 \%)$ was observed while there was no particular trend in the other months. On the other hand, of the 10 to 15 larval fish examined monthly in 1981 no empty guts were found. This observation might suggest larval fish to be feeding more frequently than the larger ones during most of the year.

The gut contents were examined by recording the number of the guts containing food. The advantage of this method is that it is quick and requires the minimum of apparatus ${ }^{4)}$ and it provides a somewhat crude qualitative picture of the food spectrum. ${ }^{5)}$ Attempts to quantitatively measure gut contents was found to result in large errors due to the small size of the gut. Therefore, only the qualitative aspects of the food organisms in the gut could be determined, thus resulting in obvious limitations to the use of this information. The use of the occurrence method does not reveal some of the important observations made during the examination of the gut contents like the seasonal variation in the number of organisms found. Most of the important food organisms in the environment as well as in the fish gut are more abundant in their number and density during the spring and summer seasons than in winter. Qualitative measurements of organisms in the environment showed a low density of organisms in winter (Table 3). This is taken as evidence that in winter the food supply is relatively low and this coupled with the low temperature decreases the feeding activity of the fish. Thus the decrease in the growth rate of the fish in winter reported 
earlier might be considered to be associated with this phenomenon.

\section{References}

1) Y. OKada: J. Fac. Fish. Pref. Univ. Mie, 4: 367411 (1959).
2) P. Spataru: Aquaculture, 11: 137-146 (1977).

3) K. Allen: J. Anim. Ecol, 4: 264-273 (1935).

4) V. IvLEv: Experimental Ecology of The Feeding of Fishes. Yale Univ. Press, New Haven, Conn. 302 pp. (1966).

5) S. Fagade and C. Olaniyan: J. Fish Biol., 4: 519-533 (1972). 